\title{
A Survey of Pre-Service Teachers ICT's Competencies in Papua
}

\author{
Martha Betaubun' \\ DOI: 10.35445/alishlah.v13i2. 651
}

\section{Article Info}

Keywords:

Preservice Teacher;

ICT Competencies;

Papua and West Papua

Kata kunci:

Guru Prajabatan;

Kompetensi ICT;

Papua dan Papua Barat

\section{Abstract}

This research analyzes the ICT Competencies of Pre-services Teachers in Papua, including the Region of Sorong, Merauke, Jayapura, and Manokwari. This research aims to discover the students of Teachers' Training Faculty spread in Papua competencies on ICT. The measurement of ICT competencies is carried out using a model developed by Tondeur for preservice teachers using questionnaires that consisted of 19 items. Questionnaires were distributed to Papua Region covering Jayapura and Merauke, West Papua region covering Sorong and Manokwari. Sixty-eight respondents became the data in this study. Data were analyzed using XL Stats to find the mean and standard deviation. The findings in this study were; the low competencies were found on Papuan Indigenous Pre-service teachers, and the high competencies were found in science discipline compared to non-science in Papua and West Papua Indonesia. The low ability of native Papuan students in managing information in the digital world is indicated by the lack of awareness of preservice teachers in developing a sense of responsibility in using ICT as a communication medium and activities involving ICT use.

\begin{abstract}
Abstrak
Penelitian ini menganalisis kompetensi TIK Guru Prajabatan di Papua meliputi Wilayah Sorong, Merauke, Jayapura, dan Manokwari dalam rangka mengkaji kompetensi TIK mahasiswa pada fakultas keguruan yang tersebar di papua. Pengukuran kompetensi TIK dilakukan dengan menggunakan model yang dikembangkan oleh Tondeur (2015) untuk guru prajabatan dengan menggunakan angket yang terdiri dari 19 item. Kuesioner disebarkan ke Wilayah Papua meliputi Jayapura dan Merauke, Wilayah Papua Barat meliputi Sorong dan Manokwari. 68-responden menjadi data dalam penelitian ini. Data dianalisis menggunakan XL Stats untuk mencari mean dan standar deviasi. Temuan dalam penelitian ini adalah; kompetensi rendah terdapat pada guru Prajabatan yang merupakan siswa asli Papua dan kompetensi tinggi terdapat pada disiplin ilmu sains dibandingkan non-sains di wilayah Papua dan Papua Barat Indonesia. Kemampuan daripada siswa asli papua yang rendah dalam mengelola informasi di dunia digital ditengarai oleh kurangnya kesadaran guru prajabatan dalam mengembangkan rasa bertanggungjawab dalam menggunakan ICT sebagai media komunikasi, dan juga aktivitas yang melibatkna penggunaan ICT.
\end{abstract}

\footnotetext{
${ }^{1}$ Universitas Musamus, Merauke, Indonesia

Email: marthabetaubun@unmus.ac.id
} 


\section{INTRODUCTION}

Technology is an inseparable part of life in the 21st century. With the rapid development of technology in recent decades, it has been widely recognized that prospective teachers must be prepared to adequately integrate information and communication technology (ICT) into their educational practices (Tondeur et al., 2017). Digital literacy skills needed by students nowadays are raised from mobile devices everywhere, the need for instant connectivity, and the increasing use of social networks among digital students (Frydenberg \& Andone, 2016).

Papua and its education that is still left behind prove the unequal education in Indonesia. The mastery of technology and its use in daily life are the main aspects to compete during the rapid development of this era. Some theorists claim that without the skills to use and evaluate digital tools now found in most informal and formal contexts, students will be 'left behind in various aspects of their lives - from work to social interaction (Chase \& Laufenberg, 2011). Therefore, according to the concern on the Indonesian Ministry of Education and Culture, technological mastery has become the primary demand where the illiteracy rate in Papua reaches $28.75 \%$ of the total 3.4 million illiterate population of Indonesia and is the highest illiterate level in Indonesia (Badan Pusat Statistik Indonesia, 2018).

Digital skills and competencies are emphasized in many national curricula (Fraillon et al., 2014). This digital literacy "involves more than the ability to use software or operate digital devices; it encompasses various complex cognitive, motor, sociological, and emotional skills that users need to function effectively in a digital environment. " (Eshet-Alkalai, 2004). Bali (2016) explains the difference in these terms: "Digital skills focus on what and how. Digital literacy focuses on why, who, and for whom. For example, teaching digital skills includes showing students how to download images from the Internet and insert them into PowerPoint slides or web pages. Digital literacy focuses on helping students choose appropriate images, recognize copyright licensing, and quote or get permission, in addition to reminding them to use alternative text for images to support those with visual limitations." The importance of the ability that must be possessed by students when graduating in the digital age is essential in producing Papuan human resources who are able to compete. An important skill added to the 'must-have' list for graduates is the ability to learn and use new technology skillfully quickly (Loizzo, Conner, \& Cannon, 2018).

As society has become increasingly digital, the demand for digitally competent teachers has evolved, forcing the need for a new approach to technology integration in education. (Instefjord \& Munthe, 2017). As a parable, efforts to increase digital capabilities have been taken by various countries. One of them is through a project called the New Millennium Learner (NML). The aim of the NML project is, on the one hand, to conceptualize and analyze from a comparative perspective the effect of new digital technology on cognitive development, values, lifestyle and educational expectations; and, on the other hand, to examine responses to the emergence of this new phenomenon in terms of educational policies and practices (Ananiadou \& Claro, 2009). In order to develop digital skills and competencies among students, teachers must meet two requirements. First, they must convey the digital competency goals set in the curriculum to students (Lee \& Tsai, 2010). Second, they must be able to use technology in their teaching to help students manage the goals of digital competence in the curriculum (Krumsvik, 2011). The benefits of using the concept of digital competence are: (1) emphasizing technical understanding, creativity, critical evaluation, and technological awareness, (2) it is a framework for understanding and developing digital competencies (Ferrari, 2013). Teacher training institutions (TTI) are thus expected to provide the competencies needed by teachers to teach with preschool services with ICT. In other words, preservice teacher ICT competencies can be established as one of the main benchmarks for teacher education programs (Kirschner, Wubbels, \& Brekelmans, 2009). Specifically on education, being able to integrate and use technology for educational purposes involves having a set of generic skills suitable for all situations, both personal and professional, and specific teacher professional skills. 
This is what is referred to as professional digital competence for teachers (Lund, Furberg, Bakken, \& Engelien, 2014).

Talk about the Papua as the focus region in this research, Juditha (2014) concluded that the people of Papua, especially in the border region, are very literate in television media. The second dominant media used is the cellular telephone, although it is limited to telephone and SMS. The Internet and radio are the least used literacy media because of inadequate infrastructure. Dong (2018) research the use of ICT in young children; nowadays, children are more brilliant in ICT than previous generations. They are active and quick to respond, and they have extensive and comprehensive knowledge and ideas. Lim (2015) discusses how the design and implementation of core teacher education courses develop the preservice teacher information communication technology (ICT) in educational competencies at universities in China. Dzikite (2017) explores the extent of lecturers' competencies in ICT support the effective implementation of ICT integrated teaching and learning and reveals that lecturers have basic skills to operate digital technology such as spreadsheets. Most lecturers cannot use other ICTs such as blogs in their teaching.

In contrast to previous research, this study explores the ability of ICT Pre-services teachers in the Papua region of Indonesia, which is the region with the lowest literacy level in Indonesia that has never been done before. To harmonize the improvement of education from the western to the eastern regions of Indonesia, assessing the condition of the quality of preservice teachers is essential. For this reason, this study provides an overview of how the conditions of ICT mastery owned by preservice teachers are.

\section{METHODS}

This research was conducted by distributing questionnaires to determine the competence of prospective ICT teachers in the institution. The process of distributing the questionnaire was carried out for two months, from February to April 2020. The sample was taken randomly but spread into two major regions in Papua island, namely Papua and West Papua. The area consisted of the Papua region covering Merauke and Jayapura and West Papua covering the Sorong and Manokwari areas. The research subject is specified as a preservice teacher. It has become the interest of researchers to examine preservice teachers because the impact will be generated as a fresh graduate in supporting technology-based learning. Researchers used a questionnaire developed by Tondeur (2017) to determine the ICT competence of preservice teachers. The distribution of the questionnaire was carried out virtually by contacting the institution that had the teaching faculty. In determining the demographic aspects to be studied, the researcher adds ethnic groups, divided into Papuan and nonPapuan natives. Furthermore, the concentration of scientific fields in the teaching faculty is divided into exact and non-exact. The questionnaire was analyzed using criteria. Interviews were conducted to be followed up into an in-depth analysis of the data obtained through questionnaires. Furthermore, the questionnaire will be analyzed using mean analysis to see the lowest and highest dominant factors in ICT mastery.

The following is a questionnaire distributed to preservice teachers in the Papua and West Papua regions wilayah:

Table 1. Items on the Questionnaire

\begin{tabular}{ll}
\hline Item 1 & Motivate pupils to use ICT in a positive way \\
\hline Item 2 & Stimulate pupils to use ICT in a critical manner \\
\hline Item 3 & $\begin{array}{l}\text { Provide pupils with activities to exercise knowledge/skills by means } \\
\text { of ICT }\end{array}$ \\
\hline Item 4 & Provide pupils with activities on subject matters to learn with ICT \\
\hline Item 5 & $\begin{array}{l}\text { Offer pupils opportunities to express ideas creatively by means of } \\
\text { ICT }\end{array}$ \\
\hline Item 6 & Support pupils in searching information by means of ICT \\
\hline Item 7 & $\begin{array}{l}\text { Support pupils in processing and managing information by means of } \\
\text { ICT }\end{array}$ \\
\hline Item 8 & Support pupils to present information by means of ICT \\
\hline
\end{tabular}




\begin{tabular}{ll}
\hline Item 9 & $\begin{array}{l}\text { Support pupils to communicate with ICT in a safe, responsible, and } \\
\text { effective way }\end{array}$ \\
\hline Item 10 & Support pupils to work together with ICT \\
\hline Item 11 & $\begin{array}{l}\text { Educate pupils to use ICT consciously (respecting ergonomics, } \\
\text { intellectual property, etc.) }\end{array}$ \\
\hline Item 12 & Select ICT applications in view of a specific educational setting \\
\hline Item 13 & (Re)design ICT applications in view of a specific educational setting \\
\hline Item 14 & Use ICT to differentiate learning and instruction \\
\hline Item 15 & Track the learning progress of pupils in a digital way \\
\hline Item 16 & Evaluate pupils with the help of ICT \\
\hline Item 17 & Use ICT appropriately to communicate with pupils \\
\hline Item 18 & Design a learning environment with the available infrastructure \\
\hline Item 19 & $\begin{array}{l}\text { Select ICT applications effectively in creating a learning } \\
\text { environment (e.g., in view of the group size) }\end{array}$ \\
\hline
\end{tabular}

Each item in the questionnaire was presented as a statement revolving around one of the three dimensions of the ICT-CF: (1) to educate pupils to become ICT competent, (2) to support and strengthen learning and development processes utilizing ICT, and (3) to organize ICT appropriately in the learning environment (Tondeur et al., 2017).

\section{FINDINGS AND DISCUSSION}

From the questionnaires distributed, as many as 68 respondents were involved in the data. The data obtained from the questionnaire were analyzed using XL Stats to find the mean and standard deviation. The following is a presentation of the data:

Table 2. Response's Mean and Standard Deviation

\begin{tabular}{ll}
\hline Mean & Std. deviation \\
\hline 4,254 & 0,859 \\
4,060 & 0,851 \\
3,179 & 1,313 \\
4,134 & 0,886 \\
4,269 & 0,809 \\
3,731 & 1,201 \\
4,194 & 0,821 \\
4,045 & 0,860 \\
1,940 & 0,952 \\
4,060 & 0,952 \\
4,299 & 0,817 \\
3,313 & 1,270 \\
3,985 & 0,844 \\
3,881 & 0,946 \\
3,582 & 1,208 \\
3,940 & 1,013 \\
3,940 & 0,919 \\
3,343 & 1,321 \\
3,955 & 0,928 \\
\hline
\end{tabular}

Based on the explanation of the mean above, it is known that questionnaire point number 9 is the lowest point. This shows that the awareness of the responsibility for using digital media for preservice teachers lies with students. So there is minimal intervention from the preservice teacher in this aspect.

Another thing that can be concluded from the mean of this analysis is that at the point of questionnaire no three, preservice teachers desire to use ICT in learning. Some although do not feel that this is a hassle and is considered time-consuming at the beginning of learning. 
Based on the questionnaire results, interviews were conducted with the ten preservice teachers to explore the causes of the low teacher intervention in building awareness of the responsibility for using digital media and the lack of use of digital media in learning.

\section{Students Responsibility in Communicating with ICT}

The main finding highlighted is the relationship between the low level of supervision and guidance of teachers towards students in communicating using ICT with the ease with which hoaxes can spread. In this case, guidance to students in filtering information circulating is undoubtedly the main thing. However, based on interviews conducted, Pre-services teachers tend to provide freedom and flexibility for students in collecting information without providing conditions so that the information obtained is accurate and valid since there is a need for digital media literacy instruction outside the traditional classroom.

From the data presented, the main thing that can be noted is the low awareness of preservice teachers in building students' awareness to communicate through ICT devices effectively, safely, and responsibly. In question item number 9, the perception of the preservice teacher is that students should be given the freedom to build communication using ICT devices. However, the control role of the preservice teacher here is not in their view. It will accumulate into a common problem, namely the spread of hoaxes that are difficult to contain. This also means the same as Toots (2004) states that access to the computer itself is not enough in providing the competencies for the students

Compared to other competencies that show that preservice teachers in Papua and West Papua have the same level of ability in encouraging students to use ICT, awareness of control over student communication in using ICT is still very weak. Based on the Ministry of Communications and Information Technology, 132.7 million active users and 800,000 sites in Indonesia spread hoaxes (Kominfo, 2017). This is a threat for students who are given the freedom to search for information on the Internet.

In 2019, South Korea, through its social media platforms, carried out an anti-hoax campaign and built digital literacy awareness among its people in collaboration with the Associated Press. This is a form of effort made by the government in a program targeted at increasing digital literacy. Indonesia, which has mapped the literacy ability of its people, can see the index of its community's ICT management and management capabilities from the digital literacy rate. This study emphasizes that the Indonesian population's low level of digital literacy can also be caused by the lack of government intervention in building programs that target digital literacy rates.

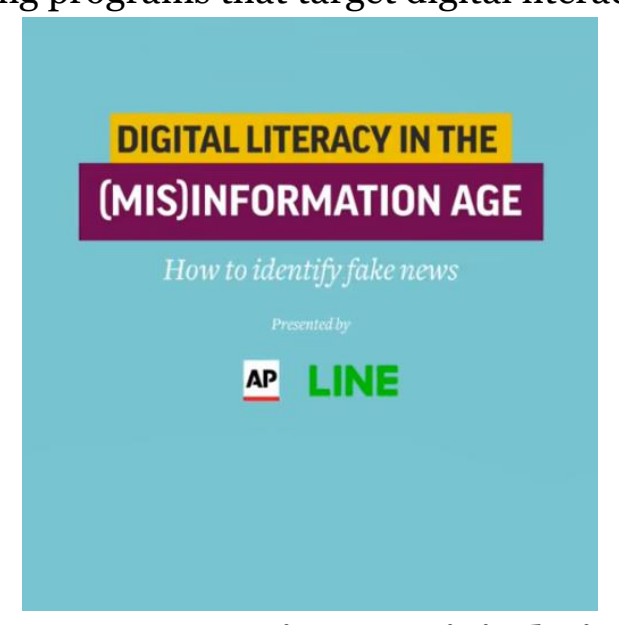

\section{Figure 1. Korean Campaign on Digital Literacy}

With the rapid development of digital platforms in Korea and the high literacy rate, campaigns on digital literacy are still being promoted to continue to improve people's digital literacy. In 2011, Korea listed itself as the country with the highest level of digital literacy among 15-year-olds based on the OECD survey. 


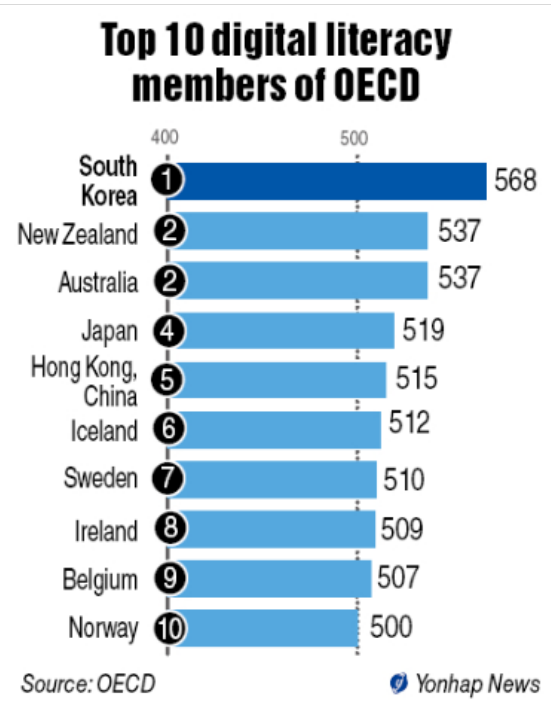

Figure 2. TOP 10 Digital Literacy Members of OECD

In contrast to the situation in Indonesia, survey data conducted by UNESCO in 2016, Indonesia was ranked 6oth out of 61 countries in the world at the level of reading literacy. Another study conducted by the Program for International Student Assessment (PISA) in the previous year showed that Indonesia's literacy rate was at a low level. Indonesia's ranking is 62 out of 70 countries. Research conducted by the Qualtrics \& Accel institute found that, on average, the millennial generation checks their smartphones 150 times every day despite low interest in reading books. However, Wearesocial released their data in January 2017 reveals that Indonesians can stare at gadget screens for approximately 9 hours a day.

The regions of Papua and West Papua themselves are vulnerable to the spread of hoaxes that are constantly threatening; this is further exacerbated by the low literacy level in this region. The importance of the role of preservice teachers in building awareness of students' responsibilities in managing information received through various tools currently available. From the interviews conducted by researchers, preservice teachers make efforts to increase awareness of their responsibility in communicating through habituation and are limited to reminding them of the importance of building healthy communication with ICT.

This effort is considered not so optimal and compared with the risks that will arise if this is not taken seriously. Indonesia, which is still far from a dream of equal distribution of education, needs to prioritize Papua and West Papua as areas that need more attention, especially in human resources management. Unfortunately, efforts to increase human resources are increasingly encountering a significant barrier due to a fundamental problem: literacy. The low literacy here makes all forms of information disseminated misused and become a boomerang for the community.

\section{Student Activities with ICT}

The teacher's role in building learning that combines ICT and student activities will significantly affect students' mastery of ICT. The low mastery of students in using ICT for learning purposes is a common thing that is encountered. Daily activities are carried out using ICT as a place to find entertainment that is embedded in students. This is due to the subordinate role of teachers in shaping students as independent learners. This can be seen from the tendency of the low response to item number 3 given by the preservice teacher, where engagement between student activities and ICT devices is still considered not so urgent.

On the other hand, as autonomous learners, students will find it easier to explore and satisfy their curiosity. The dominance of ICT as a means of seeking entertainment forms students who vent their boredom from learning. The researcher asked questions about how ICT should be in learning. The conclusions from respondents' answers lead to ICT, which should be a means of seeking 
information and entertainment only. The same thing was found in Atman's (2019) research, where the use of ICT before teaching can support teachers in designing and planning classroom activities. For the integration process to work appropriately, teachers need to identify which technology is needed, know how to use tools to meet student needs and ensure that students use the right technology at all stages of learning

Buczynski \& Mall (2010) Even in his research, he assumed that education is a conservative system. As the development of technology in the ICT field is becoming increasingly rapid, there needs to be an awareness of how ICT should be a tool to lead to renewal, not just being a connoisseur of the development of ICT itself. However, this is not the case with preservice teachers. This is where the basic demands from students come from, which must be supported by the activities provided by the preservice teacher. Activities that are mostly built from interviews conducted by researchers focus more on how students can operate ICT devices. This is a dilemma in education in the Papua and West Papua regions, where the level of mastery of technology is something that teachers still have to encourage, wherein other parts of Indonesia students have been provided with how to manage and develop information obtained from ICT devices. Even finding a preservice teacher who is still not optimal in operating ICT devices is still very easy to find. Researchers find this interesting to explore, so researchers try to find data relating to general perception rather than how important ICT is.

On the other side of the educational portrait of Papua and West Papua, there are still many schools that have to struggle in providing ICT facilities. As one of the RI-PNG border areas, Merauke can be used as an example of a portrait of education that has not been evenly distributed; even as the face of Indonesia in PNG, there are still very many schools that stand with minimal facilities. The readiness of schools in providing facilities to teachers and students and another consideration is the lack of available teachers in schools in the villages. Indeed, with equal distribution of teachers, schools will get a considerable boost in improving the quality of ongoing education. Undoubtedly, some teachers who currently do not have digital literacy and digital competence are qualified. Even the village community and the TNI independently assist the education process itself to at least the minimum standard of education can be met in the village.

\section{CONCLUSION}

Two main findings outline. The first is the low intention of preservice teachers to involve students in learning using ICT because of the difficulty and hassle that will occur when used. The second is the low inculcation of a sense of responsibility in teaching and learning. Communicate using ICT. Both of these things contribute to the ease of spreading hoaxes in the Papua region. The low level of public literacy is suspected to be the main reason for the slow improvement in this sector. The Papua region still needs attention, especially in development, especially in the field of research. In the world of education, research in the Papua region involving indigenous Papuan students will significantly impact the government's efforts to improve and equalize the quality of human resources. In terms of equity, various aspects can be studied, both in literacy and other abilities needed by learners in the 21st century, by involving native Papuan students as targets.

\section{REFERENCES}

Ananiadou, K., \& Claro, M. (2009). 21st century skills and competences for new millennium learners in OECD countries. OECD Education Working Papers, (41), 33. https://doi.org/10.1787/218525261154

Atman Uslu, N., \& Usluel, Y. K. (2019). Predicting technology integration based on a conceptual framework for ICT use in education. Technology, Pedagogy and Education, 28(5), 517-531. https://doi.org/10.1080/1475939X.2019.1668293

Bali, M. (2016). Knowing the difference between digital skills and digital literacies, and teaching both.

Buczynski, J. A., \& Mall, S. R. (2010). Developing faculty ICT competencies inside and outside the library. Internet Reference Services Quarterly, 15(2), 87-96. https://doi.org/10.1080/10875301003757211

Chase, Z., \& Laufenberg, D. (2011). Embracing the Squishiness of Digital Literacy. Journal of 
Adolescent \& Adult Literacy, 54(7), 535-537. https://doi.org/10.1598/jaal.54.7.7

Dong, C. (2018). 'Young children nowadays are very smart in ICT'-preschool teachers' perceptions of ICT use. International Journal of Early Years Education, o(o), 1-14. https://doi.org/10.108o/o9669760.2018.1506318

Dzikite, C., Nsubuga, Y., \& Nkonki, V. (2017). Lecturers' Competencies in Information and Communication Technology (ICT) for Effective Implementation of ICT-Integrated Teaching and Learning in Textiles and Clothing Degree Programmes. International Journal of Educational Sciences, 17(1-3), 61-68. https://doi.org/10.1080/09751122.2017.1305756

Eshet-Alkalai, Y. (2004). Digital literacy: A conceptual framework for survival skills in the digital era. Journal of Educational Multimedia and Hypermedia, 1(13), 93-106.

Ferrari, A. (2013). DIGICOMP: A framework for developing and understanding digital competence in Europe. Luxembourg. JRC Scientific and Policy Reports.

Fraillon, J., Ainley, J., Schulz, W., Friedman, T., \& Gebhardt, E. (2014). Preparing for Life in a Digital Age. The IEA International Computer and Information Literacy Study International Report.

Frydenberg, M., \& Andone, D. (2016). Interactive Technology and Smart Education Creating microvideos to demonstrate technology learning and digital literacy Creating micro-videos to demonstrate technology learning and digital literacy. Interactive Technology and Smart Education Iss Interactive Technology and Smart Education, 13(4), 261-273. Retrieved from http://dx.doi.org/10.1108/ITSE-09-2016-0030

Indonesia, B. P. S. (2018). Statistik Telekomunikasi Indonesia.

Instefjord, E. J., \& Munthe, E. (2017). Educating digitally competent teachers: A study of integration of professional digital competence in teacher education. Teaching and Teacher Education, 67, 37-45. https://doi.org/10.1016/j.tate.2017.05.016

Juditha, C. (2014). Tingkat Literasi Media Masyarakat di Wilayah perbatasan papua. Journal Communication Spectrum, 3(2), 107-120.

Kirschner, P., Wubbels, T., \& Brekelmans, M. (2009). Benchmarks for teacher education programs in the pedagogical use of ICT. In J. International Handbook of Information Technology in Primary and Secondary Education, 435-447.

Krumsvik, R. J. (2011). Digital competence in Norwegian teacher education and schools. Högre Utbilding, 1, 39-51.

Lee, M. H., \& Tsai, C. C. (2010). Exploring teachers' perceived self efficacy and technological pedagogical content knowledge with respect to educational use of the World Wide Web. Instructional Science, (38), 1-21. https://doi.org/doi:10.1007/ s11251-008-9075-4.

Lim, C. P., Yan, H., \& Xiong, X. (2015). Development of preservice teachers' information and communication technology (ICT) in education competencies in a mainland Chinese university. Educational Media International, $52(1), \quad 15-32$. https://doi.org/10.108o/09523987.2015.1005425

Loizzo, J., Conner, N. W., \& Cannon, K. J. (2018). Project-Based Learning for Developing Digital Literacy in Undergraduate Science Communication. NACTA Journal, 62(2), 142-150. Retrieved

from https://search.proquest.com/docview/2054106938?accountid=26642\%oAhttp://link.periodi cos.capes.gov.br/sfxlcl41?url_ver=Z39.88-

2004\&rft_val_fmt=info:ofi/fmt:kev:mtx:journal\&genre=article\&sid=ProQ:ProQ\%3Aengineer ingjournals\&atitle $=$ Project-Based+Learning + for +

Lund, A., Furberg, A., Bakken, J., \& Engelien, K. L. (2014). What does professional digital competence mean in teacher education? Nordic Journal of Digital Literacy, 4(9).

Tondeur, J., Aesaert, K., Pynoo, B., van Braak, J., Fraeyman, N., \& Erstad, O. (2017). Developing a validated instrument to measure preservice teachers' ICT competencies: Meeting the demands of the 21st century. British Journal of Educational Technology, 48(2), 462-472. https://doi.org/10.1111/bjet.12380

Toots, A., \& Laanpere, M. (2004). Tiger in focus-a national survey of ICT in estonian schools. Educational Media International, https://doi.org/10.1080/0952398032000105049 